\title{
Effect of preventive zinc supplementation on linear growth in children under 5 years of age in developing countries: a meta-analysis of studies for input to the lives saved tool
}

Aamer Imdad, Zulfiqar A Bhutta*

\begin{abstract}
Introduction: Zinc plays an important role in cellular growth, cellular differentiation and metabolism. The results of previous meta-analyses evaluating effect of zinc supplementation on linear growth are inconsistent. We have updated and evaluated the available evidence according to Grading of Recommendations, Assessment, Development and Evaluation (GRADE) criteria and tried to explain the difference in results of the previous reviews.

Methods: A literature search was done on PubMed, Cochrane Library, IZiNCG database and WHO regional data bases using different terms for zinc and linear growth (height). Data were abstracted in a standardized form. Data were analyzed in two ways i.e. weighted mean difference (effect size) and pooled mean difference for absolute increment in length in centimeters. Random effect models were used for these pooled estimates. We have given our recommendations for effectiveness of zinc supplementation in the form of absolute increment in length $(\mathrm{cm})$ in zinc supplemented group compared to control for input to Live Saves Tool (LiST).

Results: There were thirty six studies assessing the effect of zinc supplementation on linear growth in children $<5$ years from developing countries. In eleven of these studies, zinc was given in combination with other micronutrients (iron, vitamin A, etc). The final effect size after pooling all the data sets (zinc \pm iron etc) showed a significant positive effect of zinc supplementation on linear growth [Effect size: 0.13 ( $95 \% \mathrm{Cl} 0.04,0.21)$, random model] in the developing countries. A subgroup analysis by excluding those data sets where zinc was supplemented in combination with iron showed a more pronounced effect of zinc supplementation on linear growth [Weighed mean difference 0.19 (95\% Cl $0.08,0.30)$, random model]. A subgroup analysis from studies that reported actual increase in length $(\mathrm{cm})$ showed that a dose of $10 \mathrm{mg}$ zinc/day for duration of 24 weeks led to a net a gain of $0.37( \pm 0.25) \mathrm{cm}$ in zinc supplemented group compared to placebo. This estimate is recommended for inclusion in Lives Saved Tool (LiST) model.
\end{abstract}

Conclusions: Zinc supplementation has a significant positive effect on linear growth, especially when administered alone, and should be included in national strategies to reduce stunting in children $<5$ years of age in developing countries.

\section{Introduction}

The association of zinc deficiency with growth retardation and hypogonadism was first described in 1963 from Iran [1] and is now well established from animal and human studies demonstrating that zinc plays a critical role in cellular growth, cellular differentiation and metabolism [2].

\footnotetext{
* Correspondence: zulfiqar.bhutta@aku.edu

Division of Women and Child Health, Aga Khan University, Karachi, Pakistan
}

Several studies have been conducted to explore the effect of zinc supplementation on children's growth. Although there have been several reviews published on this topic, to date few meta-analyses have been published in this regard [3-5]. The two meta-analyses by Brown et al. [3,4] that included studies of zinc supplementation in pre-pubertal children concluded that zinc supplementation produces highly significant positive effect on height gain. In contrast, a recent meta-analysis 
by Ramakrishnan et al. [5] concluded that zinc supplementation was not associated with any significant positive effect on linear growth in children $<5$ years of age.

We have reviewed the available literature and evaluated the quality of included studies according to Child Health Epidemiology Reference Group (CHERG) adaptation of Grading of Recommendations, Assessment, Development and Evaluation (GRADE) criteria [6,7]. We have updated the previous meta-analyses and have tried to explore and explain the difference in results of the above mentioned meta-analyses. We have also generated an estimate for actual increase in length $(\mathrm{cm})$ for input into Lives Saved Tool (LiST) model for a standard dose and duration of zinc supplementation in children $<5$ years in developing countries.

\section{Methods \\ Searching}

To evaluate the effect of zinc supplementation on linear growth, we conducted a literature search on PubMed, Cochrane Library, IZiNCG database and WHO regional databases library as well as a manual check of available reviews and previous meta-analyses on the subject. There was no language restriction. The following search strategy was used for literature search: ("growth" OR "height" OR "weight" OR "stunting" OR growt" OR heigh" OR weigh" OR stuntin") AND ("Zinc" OR "Zinc sulphate") and limited to "clinical trial" and "humans". The last date of search was March 3rd 2010.

\section{Inclusion/exclusion criteria}

The following inclusion criteria were used to identify the studies for data abstraction: a) the study was a randomized, placebo-controlled intervention trial conducted in a developing country b) the subjects were children less than 5 year of age c) the subjects were not premature infants; d) the subjects were free of chronic diseases, such as sickle cell disease, cystic fibrosis, or severe protein-energy malnutrition e) zinc was the only component of the supplement that differed between treatment groups and $\mathrm{f}$ ) the supplemental zinc was provided for at least $\geq 8$ weeks. There was no restriction on dose of zinc supplemented or formula used (e.g. Zinc sulphate or Zinc Gluconate etc). The developing countries were defined as countries with Gross National Income per capita (GNI) below US $\$ 11,905$, according to World Bank [8]. We excluded studies where zinc was provided in fortified food as this was considered a different intervention that has been reviewed elsewhere [9].

\section{Data abstraction and validity assessment}

For quality assessment, data were abstracted into standardized forms using variables as study identifiers and context, study design and limitations, intervention specifics, and outcome effects [7]. Two authors entered the data and discrepancies were removed, if found. Individual studies were graded according to strengths and limitations of the study. Studies received an initial score of high if a randomized or cluster randomized trial and then the grade was decreased for each study design limitation, if applicable. A study was downgraded if there were limitations in the conduct of studies e.g. inadequate methods of sequence generation or allocation concealment and/or high loss to follow up ( $>20 \%)$. Risk of bias in the included studies was assessed according to latest Cochrane handbook and findings are presented in Additional File 1. Finally each study was assigned a final quality grade of "high" "moderate" "low" or "very low" on the basis of strengths and limitations of study $[6,10]$. Studies receiving a grade of 'very low' were excluded from the analysis. The grading of overall (pooled) evidence was based on three components: (1) the volume and consistency of the evidence; (2) the size of the pooled effect and (3) the strength of the statistical evidence reflected in the p-value [10]. A similar grading of 'high' 'moderate' 'low' and 'very low' was used for grading the overall evidence indicating the strength of an effect of the intervention on specific health outcome [10].

\section{Quantitative data synthesis}

The primary outcome was change in height [expressed in cms or height-for-age $\mathrm{Z}$ score (HAZ)]. For studies where mean change in height was not reported, it was calculated as the difference of mean post- and pre-intervention measurements. If studies did not report the standard deviation (SD) for change in height, it was calculated assuming that the correlation between the preand post-test variances was equal to the average correlation found in available studies. If studies reported the standard error (SE), we calculated SD by multiplying SE with square root of sample size. For studies that had different sample sizes at the beginning and the end of the intervention, the lower value of the two was used in analysis. The assessment of statistical heterogeneity in the pooled analysis was done by visual inspection i.e. the overlap of the confidence intervals among the studies, Chi square (P-value) of heterogeneity in the metaanalyses and $\mathrm{I}^{2}$ statistics. A low P value (less than 0.10 ) or a large chi-squared statistic relative to its degree of freedom and $\mathrm{I}^{2}$ values greater than $50 \%$ were taken as substantial and high heterogeneity. In situations of substantial or high heterogeneity being present, causes were explored by sensitivity analysis and random effects model were used.

In studies with factorial design i.e. (two or more intervention comparisons carried out simultaneously in a single study), only data in which zinc was the only 
difference between the two groups were included. For example, for iron-zinc factorial trials, results were included for comparisons of zinc only vs. placebo and zinc plus iron vs. iron only. In case of cluster randomized trials, cluster adjusted values were used.

Data were analyzed in two ways. In first analysis, we pooled the studies to get a weighted mean difference also called effect size. This value, also known as Cohen's effect size, is useful in meta-analyses because it eliminates the problems of units of measurement (e.g. change in height in $\mathrm{cm}$ or HAZ scores) and duration, which may vary across studies $[11,12]$. These effect sizes were calculated for individual studies by dividing the difference between the mean change in treatment and control groups by the pooled standard deviation. Random effect models were used for the primary analysis [13]. We did a subgroup analysis for data sets where zinc was supplemented alone by excluding those data sets where it was given in combination with iron. This was based on results of some experimental studies that had shown that iron may decrease the absorption of zinc when supplemented together $[14,15]$. We hypothesized that the preventive effect of zinc for stunting would be more prominent if supplemented alone rather than in combination with iron.

In the second analysis, we pooled the studies reporting change in height in cms to get a net change in length in intervention group compared to control. We also did a post hoc subgroup analysis for different daily dosages of zinc supplementation to get a point estimate for inclusion in the Live Saved Tool (LiST). More details about this analysis are provided in the results section (Recommendations for LiST model). All the meta-analyses were conducted using software Review Manager version 5 [16].

\section{Results}

\section{Trial flow}

From literature search, 447 titles were identified (Fig: 1). We scanned the titles and abstracts of the trials identified to exclude those that were obviously irrelevant, retrieved the full text of the remaining trials, and identified relevant articles. Initially, 49 studies were selected for detailed review. Five of these studies were not included in the final analysis because the participants were $>5$ years of age [17-22]. Four studies were excluded from analysis because they were from developed countries [23-26], as per objectives of LiST model. Two studies were excluded because the duration of supplementation was $<8$ weeks $[27,28]$. One study was excluded because it included only premature babies [29]. Three studies were excluded because children had severe protein energy malnutrition [30-32]. Finally, 36 studies were selected for data abstraction [33-68].

\section{Study characteristics}

Table 1 presents the characteristics of included studies. All the included studies were randomized controlled trials. In 25 studies zinc was supplemented alone while in 11 studies some of the study groups also received other micronutrients (iron, folic acid, vitamin A) [47,51,52,54,58,59,61-63,65,68]. Mean initial height for age $\mathrm{Z}$ score (HAZ) ranged from -2.91 [37] to -0.08 [33], and the mean initial age ranged from less than one month [50] to 55 months[40]. The average daily dose (calculated by dividing the total weekly doses by 7 ) of zinc supplementation ranged from $1 \mathrm{mg} /$ day [41] to 20 $\mathrm{mg} /$ day [53] with a median of $10 \mathrm{mg} /$ day. Most studies $(n=28)$ provided the zinc supplements in the form of zinc sulphate, although 5 used zinc acetate $[36,44,48,53,56]$ and 2 used zinc gluconate $[34,55]$. The mean duration of intervention ranged from 8 weeks [41] to 64 weeks [35] with a median of 24 weeks. All the included studies were published between 1992 and 2009 (median: 1998). Fourteen of these studies were conducted in Latin America or the Caribbean, 16 in Asia, and 6 in Africa. Additional File 1 presents the risk of bias table for included studies.

\section{Effect on linear growth}

Information on change in height (in cm or HAZ scores) was available from 35 studies, which contained 47 group wise comparisons. In study by Fahmida et al. 2007 [62], only one data set was included in analysis (zinc alone vs. placebo) because comparison groups for other data sets (zinc + iron, zinc + iron + vitamin A) were not appropriate (no iron only or iron + vitamin A group). In study by Brown et al. 2007 [67], there were three intervention groups i.e. placebo, zinc alone (solution form) and zinc (in fortified food). We included comparison of zinc (solution form) vs. placebo and not that of zinc in fortified food vs. placebo. Iron was supplemented to both groups in study by Alarcon et al. 2004 [51]. This study had been included in analysis of zinc + iron vs. iron alone and not that of zinc alone vs. control comparison.

Our meta-analysis of available studies suggested that zinc supplementation is associated with a net benefit on linear growth. The estimated effect size (weighed mean difference) for zinc supplementation on linear growth including results from all data sets (zinc \pm iron) was 0.13 [95\% CI 0.04, 0.21] (Figure 2). When data sets with zinc + iron were excluded from analysis, the final effect size was 0.19 [95 \% CI 0.08, 0.30] (Figure 3). We also separately pooled results of data sets where zinc was given in combination with Iron (data not shown). The pooled estimate for zinc plus iron versus control was -0.10 [95\% CI $-0.21,0.01]$. These results were significantly different from overall estimate $(\mathrm{p}=0.0001)$. This 


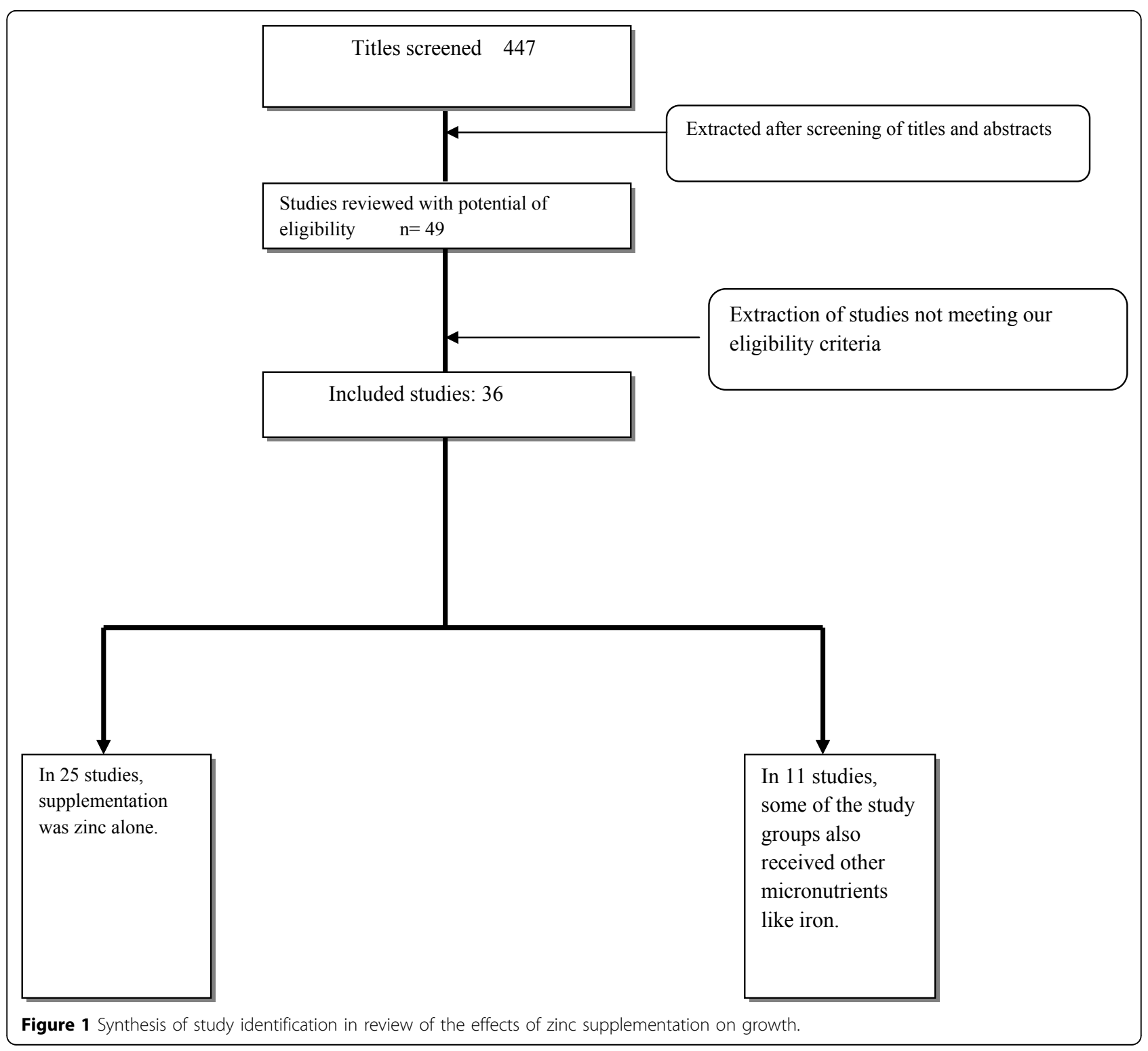

shows that zinc supplementation alone has more prominent effects on length gain than when supplemented in combination with iron. Due to this reason, we would base our recommendations for LiST model on the basis of results of zinc supplementation alone in the next section.

\section{Recommendations for LiST model}

Results of effect size (weighed mean difference) are interpreted as the percent of non-overlap of the intervention group's scores with those of the control group. An effect size (ES) of 0.0 indicates that the distribution of scores for the intervention group overlaps completely with the distribution of scores for the control group, and there is $0 \%$ non-overlap. An ES of 0.3 indicates a non-overlap of $21.3 \%$ in the two distributions. Effect size can be categorized as small $(\sim 0.2)$, medium $(\sim 0.5)$ or large $(\sim 0.8)$ [11]. This shows that results of pooled effect size can only be interpreted as percent of non-overlap of results of two groups and an absolute quantitative estimate cannot be generated in the form of units of measurement [69].

In order to translate the observed weighed mean effect size into practical recommendations, we reanalyzed the subset of 28 studies that presented results in terms of absolute height increments in centimeters. The pooled results from 32 data sets of these studies showed a net gain of $0.36( \pm 0.18) \mathrm{cm}$ in the zinc supplemented group compared to control in children $<5$ years of age in developing countries (Figure 4). The mean duration of 
Table 1 Characteristics of included studies

\begin{tabular}{|c|c|c|c|c|c|c|c|c|}
\hline Study ID (ref) & Country & $\begin{array}{l}\text { Sample } \\
\text { size }(n)\end{array}$ & $\begin{array}{l}\text { Mean initial } \\
\text { age (months) }\end{array}$ & $\begin{array}{l}\text { Dose } \\
\text { (mg/ } \\
\text { day) }\end{array}$ & $\begin{array}{l}\text { Duration } \\
\text { (weeks) }\end{array}$ & $\begin{array}{l}\text { Mean initial } \\
\text { height }(\mathrm{cm})\end{array}$ & $\begin{array}{l}\text { Mean initial } \\
\text { HAZ score }\end{array}$ & $\begin{array}{l}\text { Grade (High, } \\
\text { moderate and } \\
\text { low) }\end{array}$ \\
\hline Hong 1992[33] & China & 102 & 0 & 5 & 24 & 50.0 & -0.08 & Moderate \\
\hline Bates 1993[34] & Gambia & 110 & 18 & $\begin{array}{l}70 \\
(/ 2 w k)\end{array}$ & 64 & 76.8 & -1.57 & High \\
\hline $\begin{array}{l}\text { Dirren } 1994 \\
\text { [35] }\end{array}$ & Ecuador & 96 & 32 & 10 & 64 & 81.6 & -2.89 & Moderate \\
\hline $\begin{array}{l}\text { Castillo-Duran } \\
\text { 1995[36] }\end{array}$ & Chile & 68 & 0 & 3 & 24 & 47.2 & -1.36 & Moderate \\
\hline Ninh 1996[37] & Vietnam & 146 & 17.5 & 10 & 20 & 71.3 & -2.91 & Moderate \\
\hline $\begin{array}{l}\text { Sempertgui } \\
\text { 1996[38] }\end{array}$ & Ecuador & 50 & 42.3 & 10 & 9 & - & -2.00 & Moderate \\
\hline Ruz 1997[39] & Chile & 102 & 39.8 & 10 & 56 & 95.6 & -0.52 & High \\
\hline Rosado 1997 & Mexico & 109 & 28 & 20 & 52 & 83.4 & -1.55 & moderate \\
\hline $\begin{array}{l}\text { Gardner } 1998 \\
\text { [42] }\end{array}$ & Jamaica & 61 & 14 & 10 & 12 & 68.7 & -2.85 & High \\
\hline Lira 1998[41] & Brazil & 137 & 0 & 1 and 5 & 8 & - & - & Moderate \\
\hline $\begin{array}{l}\text { Kikafunda } 1998 \\
{[40]}\end{array}$ & Uganda & 155 & 55.8 & 10 & 24 & 103.3 & -0.70 & Moderate \\
\hline Rivera 1998[43] & Guatemala & 89 & 7.5 & 10 & 28 & 63.7 & -2.16 & High \\
\hline Smith 1999[44] & Belize & 51 & 44 & 70 & 24 & - & - & High \\
\hline $\begin{array}{l}\text { Umeta } 2000 \\
{[45]}\end{array}$ & Ethopia & 100 & 9.6 & 10 & 24 & 69.9 & -0.64 & High \\
\hline $\begin{array}{l}\text { Castillo-Duran } \\
\text { 2001[46] }\end{array}$ & Chile & 150 & 0 & 5 & 52 & 50.3 & -0.06 & High \\
\hline $\begin{array}{l}\text { Dijkhuizen } \\
\text { 2001[47] }\end{array}$ & Indonesia & 238 & 4.2 & 10 & 24 & 61.2 & -0.79 & High \\
\hline $\begin{array}{l}\text { Osendarp } 2002 \\
\text { [48] }\end{array}$ & Bangladesh & 301 & 0.9 & 5 & 20 & 51.2 & 0.00 & Low \\
\hline $\begin{array}{l}\text { Muller } 2003 \\
\text { [49] }\end{array}$ & Burkina Faso & 709 & 18.5 & 24 & 75.5 & 8.7 & -1.55 & High \\
\hline Sur 2003[50] & India & 100 & 0 & 5 & 52 & 46.4 & -1.70 & High \\
\hline Black 2004[52] & Bangladesh & 94 & 6.5 & 20 & 24 & - & -1.20 & Moderate \\
\hline Black 2004[53] & India & 200 & 1 & 5 & 32 & 47.5 & -1.20 & Moderate \\
\hline Lind 2004[54] & Indonesia & 340 & 6 & 10 & 24 & - & -0.35 & High \\
\hline $\begin{array}{l}\text { Alarcon } 2004 \\
\text { [51] }\end{array}$ & Peru & 213 & 17 & 3 & 18 & 76.8 & -1.04 & High \\
\hline $\begin{array}{l}\text { Penny } 2004 \\
\text { [55] }\end{array}$ & Peru & 246 & 19 & 10 & 24 & 76.4 & -0.16 & High \\
\hline $\begin{array}{l}\text { Gardner } 2005 \\
{[57]}\end{array}$ & Jamaica & 114 & 19 & 10 & 24 & 77.1 & -1.65 & Moderate \\
\hline Brooks2005[56] & Bangladesh & 1665 & 5.3 & $70(/ \mathrm{wk})$ & 52 & 62.7 & -1.10 & High \\
\hline $\begin{array}{l}\text { Wasantwist } \\
\text { 2006[61] }\end{array}$ & Thailand & 304 & 4.5 & 10 & 24 & 62.3 & -0.70 & High \\
\hline Silva 2006 [60] & Brazil & 58 & 23.5 & 10 & 16 & - & -1.95 & High \\
\hline $\begin{array}{l}\text { Berger } 2006 \\
{[58]}\end{array}$ & Vietnam & 391 & 5.9 & 10 & 24 & 63.8 & -1.07 & High \\
\hline Olney 2006[59] & Tanzania & 433 & 8.8 & 10 & 52 & - & -1.45 & Moderate \\
\hline $\begin{array}{l}\text { Brown } 2007 \\
\text { [67] }\end{array}$ & Peru & 302 & 7.5 & 3 & 24 & 65.4 & -1.19 & High \\
\hline $\begin{array}{l}\text { Fahmida } 2007 \\
\text { [62] }\end{array}$ & Indonesia & 399 & 5 & 10 & 24 & - & -0.99 & High \\
\hline $\begin{array}{l}\text { Wuehler } 2008 \\
\text { [64] }\end{array}$ & Ecuador & 253 & 21 & 3,7 and 10 & 24 & 77.4 & -2.30 & High \\
\hline $\begin{array}{l}\text { Dijikhuizen } \\
\text { 2008[63] }\end{array}$ & $\begin{array}{l}\text { Multicentre trial (Thailand, } \\
\text { Veitnam and Indonesia) }\end{array}$ & 2468 & 5.05 & 10 & 24 & - & -0.82 & High \\
\hline $\begin{array}{l}\text { Mozaffari- } \\
\text { Khosarvi } 2009 \\
\text { [66] }\end{array}$ & Iran & 85 & 38.8 & 5 & 24 & - & -1.65 & High \\
\hline $\begin{array}{l}\text { Walker } 2009 \\
\text { [65] }\end{array}$ & Bangladesh & 645 & 6.35 & 20 & 24 & 64.2 & - & High \\
\hline
\end{tabular}


supplementation in these studies was 7.03 months and the dose ranged from $1 \mathrm{mg} /$ day to $20 \mathrm{mg} / \mathrm{day}$. The weighed mean difference 'effect size' for these studies was 0.23 (95\% CI $0.11,0.36)$. In order to give a recommendation with a specific dose/day and for a specific duration, we did a post hoc subgroup analysis according to different dosages of daily zinc supplementation (Figure 5). This analysis showed that preventive zinc supplementation in a dose of $10 \mathrm{mg} /$ day has the most significant effect on linear length in children $<5$ years 


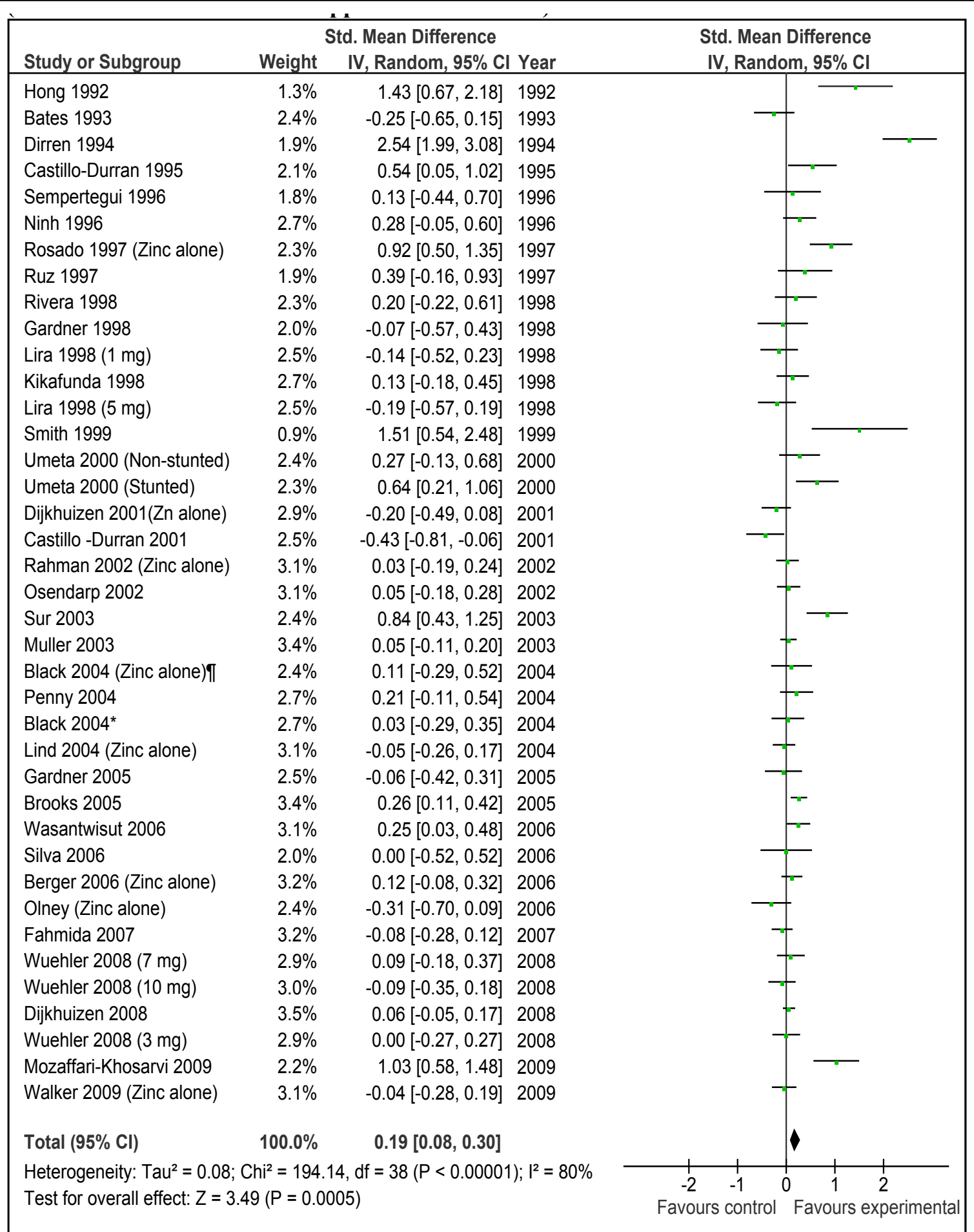

Figure 3 Effect sizes for height gain in zinc intervention trials among children less than $\mathbf{5}$ years of age in developing countries. Final estimate from 39 data sets of $\mathbf{3 4}$ studies. (Includes data sets with zinc supplementation alone).

of age [mean difference: $0.46 \mathrm{~cm}(95 \%$ CI $0.21,0.71)$, random model]. The results for dose of $5 \mathrm{mg} /$ day [mean difference 0.61 (95\% CI $-0.28,1.51)$, random model] and that of $3 \mathrm{mg} /$ day [mean difference $0.05(95 \% \mathrm{CI}$
$-0.25,0.35)$ random model] were not statistically significant. There was a significant statistical difference among these subgroups $(p=0.005)$. In the subset of studies where zinc was supplemented in a dose of $10 \mathrm{mg} / \mathrm{day}$, 


\begin{tabular}{|c|c|c|c|c|c|c|}
\hline \multirow{2}{*}{$\begin{array}{l}\text { Study or Subgroup } \\
\text { Hong } 1992\end{array}$} & \multirow{2}{*}{ Weight } & \multicolumn{2}{|c|}{$\begin{array}{l}\text { Mean Difference } \\
\text { IV, Random, } 95 \% \text { CI Year }\end{array}$} & \multicolumn{3}{|c|}{$\begin{array}{c}\text { Mean Difference } \\
\text { IV, Random, } 95 \% \mathrm{CI}\end{array}$} \\
\hline & & $1.62[0.88,2.36]$ & 1992 & & 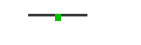 & \\
\hline Bates 1993 & $2.6 \%$ & $-0.50[-1.30,0.30]$ & 1993 & & & \\
\hline Dirren 1994 & $5.6 \%$ & $0.73[0.62,0.84]$ & 1994 & & $=$ & \\
\hline Castillo-Durran 1995 & $1.3 \%$ & $1.50[0.17,2.83]$ & 1995 & & & \\
\hline Ninh 1996 & $0.9 \%$ & $1.50[-0.25,3.25]$ & 1996 & & & \\
\hline Ruz 1997 & $3.7 \%$ & $0.40[-0.14,0.94]$ & 1997 & & - & \\
\hline Rosado 1997 (Zn alone) & $5.6 \%$ & $0.20[0.11,0.29]$ & 1997 & & $=$ & \\
\hline Kikafunda 1998 & $0.8 \%$ & $0.77[-1.04,2.58]$ & 1998 & & & \\
\hline Lira 1998 (5 mg) & $2.7 \%$ & $-0.39[-1.17,0.39]$ & 1998 & & & \\
\hline Gardner 1998 & $3.0 \%$ & $-0.10[-0.81,0.61]$ & 1998 & & & \\
\hline Lira 1998 (1 mg) & $2.0 \%$ & $-0.39[-1.38,0.60]$ & 1998 & & - & \\
\hline Rivera 1998 & $2.5 \%$ & $0.40[-0.43,1.23]$ & 1998 & & & \\
\hline Smith 1999 & $3.5 \%$ & $1.10[0.51,1.69]$ & 1999 & & $\longrightarrow$ & \\
\hline Umeta 2000 (Stunted) & $0.4 \%$ & $4.10[1.47,6.73]$ & 2000 & & & \\
\hline Umeta 2000 (Non-stunted) & $0.5 \%$ & $1.60[-0.73,3.93]$ & 2000 & & & \\
\hline Dijkhuizen 2001(Zn alone) & $3.0 \%$ & $-0.50[-1.20,0.20]$ & 2001 & & & \\
\hline Osendarp 2002 & $4.1 \%$ & $0.10[-0.35,0.55]$ & 2002 & & - & \\
\hline Sur 2003 & $1.9 \%$ & $2.30[1.24,3.36]$ & 2003 & & & \\
\hline Muller 2003 & $4.8 \%$ & $0.10[-0.23,0.43]$ & 2003 & & - & \\
\hline Black 2004* & $2.2 \%$ & $0.10[-0.83,1.03]$ & 2004 & & & \\
\hline Penny 2004 & $4.1 \%$ & $0.30[-0.15,0.75]$ & 2004 & & - & \\
\hline Brooks 2005 & $3.0 \%$ & $1.20[0.49,1.91]$ & 2005 & & 一 & \\
\hline Gardner 2005 & $0.7 \%$ & $-0.30[-2.23,1.63]$ & 2005 & & & \\
\hline Berger 2006 (Zn alone) & $3.9 \%$ & $0.14[-0.35,0.63]$ & 2006 & & - & \\
\hline Wasantwisut 2006 & $3.8 \%$ & $0.60[0.07,1.13]$ & 2006 & & - & \\
\hline Brown 2007 & $4.8 \%$ & $0.00[-0.31,0.31]$ & 2007 & & - & \\
\hline Dijkhuizen 2008(Zn alone) & $5.4 \%$ & $0.10[-0.09,0.29]$ & 2008 & & $r$ & \\
\hline Wuehler 2008 (3 mg) & $4.9 \%$ & $0.00[-0.31,0.31]$ & 2008 & & - & \\
\hline Wuehler 2008 (10 mg) & $4.9 \%$ & $-0.10[-0.41,0.21]$ & 2008 & & & \\
\hline Wuehler 2008 (7 mg) & $5.0 \%$ & $0.10[-0.19,0.39]$ & 2008 & & - & \\
\hline Walker 2009 (Zn alone) & $3.4 \%$ & $-0.10[-0.71,0.51]$ & 2009 & & - & \\
\hline Mozaffari-Khosarvi 2009 & $2.1 \%$ & $2.36[1.41,3.31]$ & 2009 & & & \\
\hline Total $(95 \% \mathrm{Cl})$ & $100.0 \%$ & $0.36[0.18,0.53]$ & & & $\downarrow$ & \\
\hline $\begin{array}{l}\text { Heterogeneity: } \operatorname{Tau}^{2}=0.14 \text {; } \\
\text { Test for overall effect: } Z=3\end{array}$ & $\begin{array}{l}h i^{2}=172 . \\
8(P<0.0\end{array}$ & $\begin{array}{l}4, d f=31(P<0.00001 \\
01)\end{array}$ & $1) ; I^{2}=82 \%$ & $\begin{array}{ccc}1 & 1 & 1 \\
-4 & -2 & 0 \\
\text { Favours control }\end{array}$ & $\begin{array}{c}2 \\
\text { Favours e) }\end{array}$ & $\begin{array}{l}4 \\
x p e r i m e n t a l\end{array}$ \\
\hline
\end{tabular}

*Black 2004 [ Study from India[53]]

Figure 4 Main gain in height (in $\mathrm{cm}$ ) in zinc supplemented (alone) group compared to control. Data from 28 studies in the form 32 data sets irrespective of dose and duration of supplementation.

duration of supplementation was 6 months in all the studies except in three studies [35,37,39]. In two of these studies the supplementation continued for a year [35,39] while in one study it was for 5 months [37]. In the study by Brooks et al. [56] the supplementation also continued until a year, however disaggregated data was available for 6 months duration. We pooled results of those studies where zinc was supplemented in a dose of $10 \mathrm{mg} /$ day for duration of 24 weeks by excluding the three above mentioned studies [35,37,39]. Combined results from these studies showed a net gain in length of $0.37 \mathrm{~cm}( \pm 0.25)$ in zinc supplemented group compared to placebo (Figure 6). Table 2 summarizes the quality assessment and pooled estimate for this outcome. The qualitative assessment of the available evidence for the effect of zinc supplementation $(10 \mathrm{mg} /$ day for 24 weeks) on linear growth was that of 'moderate' level. This qualitative grading for collective evidence is 
based on the parameters such as volume and consistency of the evidence, the size of the effect and the strength of the statistical evidence for an association between the intervention and outcome [10].

On the basis of qualitative grading of collective evidence and specificity of intervention in terms of dose and duration, we have recommended this estimate for input to LiST model. This can be described as follows; "preventive zinc supplementation in a dose of $10 \mathrm{mg} /$ day for 24 weeks in children $<5$ years of age leads to a net gain of $0.37 \mathrm{~cm}$ in zinc supplemented group compared to control in developing countries". 


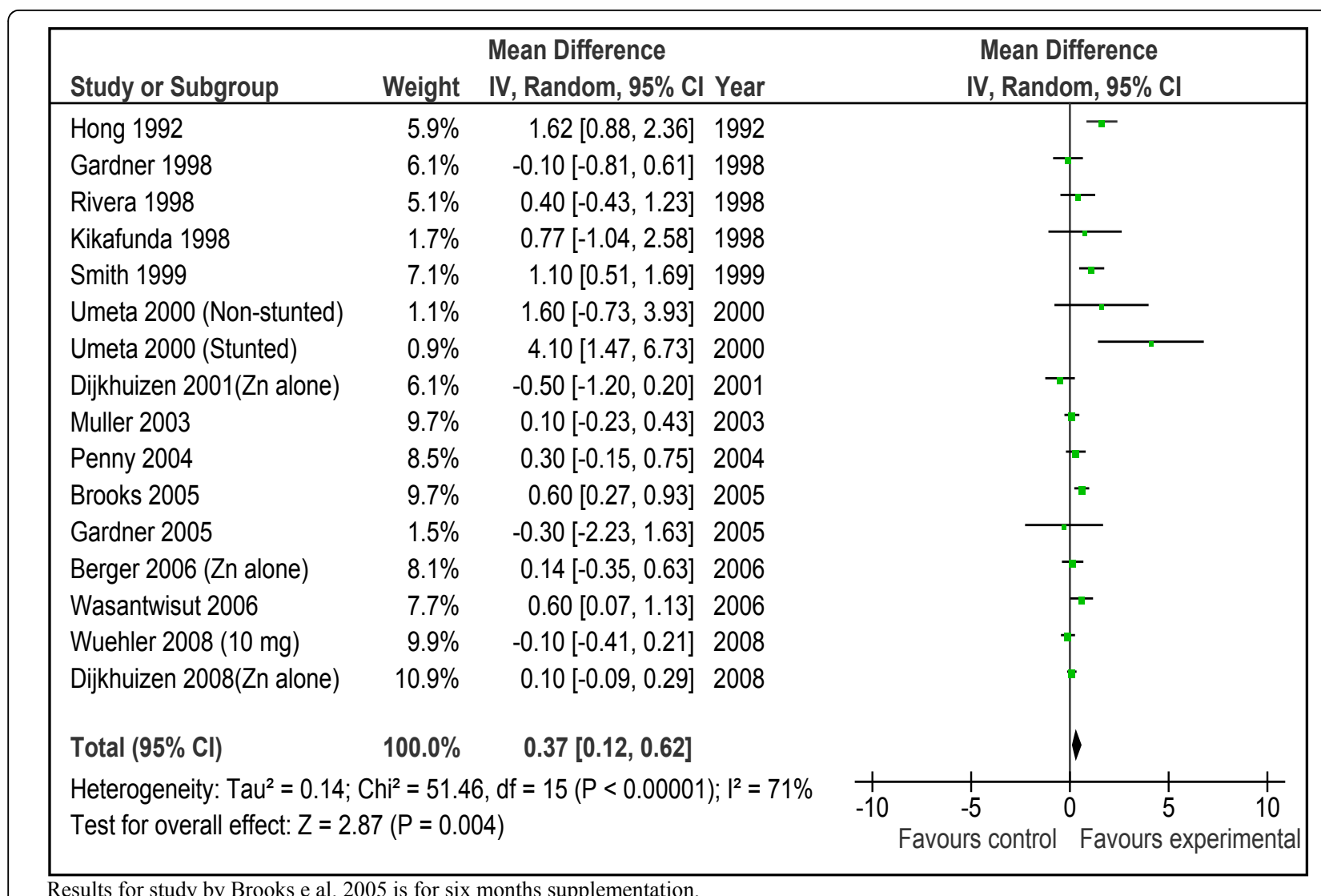

Figure 6 Mean gain in height $(\mathrm{cm})$ after $10 \mathrm{mg}$ zinc supplementation alone for 24 weeks in children $<5$ years of age in developing countries.

\section{Discussion}

Effect of zinc supplementation on linear growth has been evaluated previously [3-5]. The first and most widely known meta-analysis evaluating the effect of zinc supplementation on growth was conducted by Brown et al in 2002 [4]. This review included studies with children until pre-puberty and studies from both developing and developed countries. Pooled results from 33 studies showed that zinc supplementation had a highly significant positive effect on linear growth (effect size $=0.350$, 95\% CI: 0.189, 0.511). In the latest review published by the same authors [3], more studies have been added to the previous (2002) analysis and the beneficial effect remained significant [effect size $=0.170$ (95\% CI: 0.075, $0.264)$ ]. In contrast, another meta-analysis by Ramakrishnan et al. based on 43 studies found no significant

Table 2 Qualitative assessment of Trials for effect of zinc supplementation on linear growth

\begin{tabular}{|c|c|c|c|c|c|c|c|}
\hline \multicolumn{6}{|c|}{ Quality Assessment } & \multicolumn{2}{|c|}{ Summary of findings } \\
\hline & & & & \multicolumn{2}{|l|}{ Generalizability } & $\begin{array}{l}\text { Pooled } \\
\text { Effect }\end{array}$ & $\begin{array}{l}\text { Qualitative } \\
\text { Assessment }\end{array}$ \\
\hline No. of studies & Design & Limitations & Consistency & $\begin{array}{l}\text { Generalizability } \\
\text { to Population } \\
\text { of Interest }\end{array}$ & $\begin{array}{l}\text { Generalizability } \\
\text { to intervention } \\
\text { of Interest }\end{array}$ & $\begin{array}{l}\text { Mean } \\
\text { Difference } \\
\text { ( } 95 \% \text { Cl) }\end{array}$ & $\begin{array}{l}\text { High, } \\
\text { moderate, } \\
\text { low, very } \\
\text { low) }\end{array}$ \\
\hline \multicolumn{8}{|c|}{ Effect of Zinc supplementation on linear growth: Zinc supplementation for a dose of $10 \mathrm{mg} /$ day for a duration of 24 weeks } \\
\hline $\begin{array}{l}15 \\
{[33,40,42-45,47,49,55-58,61,63,64]}\end{array}$ & $\mathrm{RCT}$ & $\begin{array}{l}\text { In one study [49], dose was } \\
\text { not exact } 10 \mathrm{mg} / \text { day but } \\
\text { was } 12.5 \mathrm{mg} / \text { day. } \\
\text { Supplementation in one } \\
\text { study continued till } 28 \\
\text { weeks [43]. }\end{array}$ & $\begin{array}{l}\text { Heterogeneity } \\
71 \% \text {. Random } \\
\text { effect models } \\
\text { used. }\end{array}$ & $\begin{array}{c}\text { All the studies } \\
\text { from } \\
\text { developing } \\
\text { countries }\end{array}$ & $\begin{array}{l}10 \mathrm{mg} \text { zinc/day } \\
\text { for } 24 \text { weeks }\end{array}$ & $\begin{array}{l}0.37(0.12- \\
0.62) \mathrm{cm}\end{array}$ & Moderate \\
\hline
\end{tabular}


effect of zinc supplementation on linear growth [effect size $=0.07$ (95\% CI: $-0.03,0.17)]$ in children $<5$ years of age [5]. Our results from included studies from developing countries and with children $<5$ years of age showed that preventive zinc supplementation (zinc \pm iron) had a significant effect on linear growth [Effect size $=0.13$ (95 $\%$ CI $0.04,0.21$ )]. If we include results from four excluded studies from developed countries [23-26], the effect size comes to be 0.14 (95\% CI 0.05-0.22) and if the results of studies with children $>5$ years are included, the estimate becomes 0.15 (95\% CI 0.07 , $0.23)$.

Our results are in concordance with that of Brown et al. 2009 [3] but at variance with the findings of Ramakrishnan et al 2009 [5]. What are the reasons for these contradictory findings and the differences between these reviews? The main differences were in inclusion and exclusion criteria. We and Ramakrishnan et al (5) included studies with children $<5$ years, while Brown et al. (3) also included children until pre-pubertal age. Both Brown et al. (3) and we excluded studies where zinc was supplemented in fortified foods, while Ramakrishanan et al. (5) included these as well. Brown et al. (3) also excluded those studies where SD for change in length was not reported in the paper; however we and Ramakrishnan included those (5). Do these differences explain the reasons for contradictory results? If we include zinc fortified studies with our analysis (all countries), the estimated effect size becomes 0.15 (95\% CI $0.06,0.20$ ), which indicates that excluding zinc fortification studies did not significantly alter the results and direction of effect. Excluding children $>5$ years also did not change the results significantly as shown above. We could not find any further explanation for the difference in results of our analysis and these reviews.

Presentation of results in terms of absolute difference in the growth increment is described in previous reviews. In the previous review by Brown et al. in 2002 (4) data were analyzed in two ways i.e. pooled weighted mean difference (results discussed above) and actual increase in length $(\mathrm{cm})$ [4]. In the second analysis, they pooled results from 25 studies to get a net increment in length of $0.73( \pm 0.98) \mathrm{cm}$ in zinc supplemented group compared to controls. These results were not however described for any particular dose or duration and the meta-views were also not provided to get an idea of the contribution of each study. On the other hand we have described pooled results for all the studies that reported absolute increment in length and also did a subgroup analysis for the most effective dose for a particular duration. This leads to an estimated effect size of 0.37 $( \pm 0.25) \mathrm{cm}$ increase in linear growth in children $<5$ years, with a specific dose of $10 \mathrm{mg}$ zinc/day for a duration of 24 weeks (Fig 3). The p-value for this estimate was 0.005 and quality grade for the pooled evidence was that of 'moderate' level. The most prominent contribution to this estimate comes from study by Umeta et al. in stunted children [45]. This is understandable, as zinc seems to have more prominent effect on growth in stunted compared to non-stunted children [4]. If results of this data set are omitted from analysis, the estimate becomes $0.36( \pm 0.26) \mathrm{cm}$. In any case, keeping in mind the statistical significance, quality grade and specificity of estimate, this seems to be the most suitable input to LiST model, for an effect size estimate of zinc supplementation in prevention of stunting in children $<5$ years of age in developing countries.

What does an extra gain of $0.37 \mathrm{~cm}$ means clinically? An average gain of this much in height would not be a huge effect but we need to take into account that that a single micronutrient would not be expected to result in such a substantial benefit at the first place. The results of this review confirms that preventive zinc supplementation indeed has an effect in promotion of growth of young children but this has to be connected with more comprehensive approaches that improve the diets of small children in general to get a more substantial effect. These efforts should especially focus on first two years of life and there should be a special attention to promote exclusive breastfeeding and practices of complementary feeding in addition to correcting micronutrient deficiencies. An analysis published in lancet undernutrition series in 2008 showed that education and counseling of caretakers in food-secure populations can improve growth in height (WMD 0.25; 95\% CI: $0.01,0.49$ ) and providing complementary food, with or without education and counseling, can improve height in food insecure populations (WMD 0.41; 95\% CI: 0.05, 0.76) [70]. In an updated analysis for this series, we have shown that provision of complementary food ( \pm nutrition counseling) lead to an extra gain of $0.54 \mathrm{~cm}( \pm 0.38)$ and education of mothers about complementary feeding can lead to an extra gain of $0.49 \mathrm{~cm}( \pm 0.50)$ in the intervention group compared to control [71]. Thus, in order to get full advantage of relatively small benefit of correcting zinc deficiency, we must, at the same time, focus on interventions to improve complementary feeding and general nutritional status if the child. Future research should focus on strategies where correction of micronutrient deficiencies should be a part of a more general approach to improve the nutritional status of the child in general.

Do zinc and iron interact significantly when supplemented simultaneously? It has been demonstrated from several studies that iron and zinc have similar absorption and transport mechanisms [72]. Experimental studies have also shown that simultaneous supplementation of iron and zinc may inhibit zinc absorption in these 
cells especially at high ratios of iron to zinc [14,15,73]. A review by Walker et al. (64) on interaction of zinc and iron in supplementation trials showed that combined supplementation of zinc and iron did not affect the biochemical status of zinc; however the data were not clear regarding morbidity and growth outcomes. In our review, subgroup analysis excluding studies in which zinc was co-administered with iron showed an increase in overall effect size confirming the likelihood of interaction (Fig 2). When we separately pooled these data sets (zinc + iron), the pooled effect size showed a negative trend -0.10 [95\% CI $-0.21,0.01]$. These results were significantly different from overall estimate $(\mathrm{p}=0.0007)$. These analyses strongly suggest that addition of iron decreases the positive effect of zinc supplementation on linear growth through potential interference with absorption or bio-availability. We have, therefore, presently restricted our recommendation for zinc supplementation to studies with zinc supplementation alone.

We used rigorous eligibility criteria for inclusion of studies. For example, the minimum period of supplementation should be $\geq 8$ wk because shorter periods may be insufficient for detecting a linear growth response. Furthermore, we excluded studies of premature infants and those suffering from chronic disease or severe protein-energy malnutrition as zinc requirements of these children might differ considerably from those of unaffected children $[74,75]$. We also excluded studies in which zinc was supplemented in fortified food. Although tracer-element experimental studies had shown that zinc fortification of food increase total zinc absorption [76-78], relatively few community studies have found positive impacts of zinc fortification on serum zinc concentrations or functional indicators of zinc status [3]. There is also insufficient evidence for ideal food vehicle for zinc fortification and also interaction of zinc with other micronutrient when fortified in a single food [9].

Preventive zinc supplementation seems to be a safe intervention. It has been suggested that high levels of zinc intake may interfere with normal iron and copper metabolism [76]. Although we did not specifically look at adverse effects, results from previous reviews showed that preventive zinc supplementation in physiological doses do not significantly affect the indicators of iron (i.e. hemoglobin and/or ferritin level) and/or copper metabolism [3].

Our review has certain limitations. As our recommendations are limited to zinc supplementation alone vs. control/placebo, these results may not be readily applicable to countries where there are on-going national supplementation programs of iron-folate, for example, India. We expect that policy makers will assess local contexts and conditions while considering the feasibility of zinc supplementation programs. We were unable to identify any significant predictor of substantial heterogeneity in the pooled data. There may be factors, not examined by us, that might explain the observed differences. These include initial HAZ score (prevalence of stunting), mean initial age, baseline zinc deficiency, gender and HIV prevalence [4,79-81]. Although there are relatively large number of studies and a funnel plot for zinc alone supplementation was relatively symmetrical (data not shown), there may be possible publication bias.

In conclusion, our review suggests that zinc supplementation has a positive effect on linear growth, especially when supplemented alone. Zinc supplementation in a dose of $10 \mathrm{mg} /$ day for duration of 24 weeks led to an increase gain in length by $0.37( \pm 0.25) \mathrm{cm}$ among children $<5$ years of age in developing countries compared to controls.

\section{Additional material}

Additional File 1: Risk of bias for the included studies according to the latest recommendations of the Cochrane Handbook

\section{Acknowledgment}

This work was supported in part by a grant to the US Fund for UNICEF from the Bill \& Melinda Gates Foundation (grant 43386) to "Promote evidencebased decision making in designing maternal, neonatal and child health interventions in low- and middle-income countries". We thank Dr Mohammad Yawar Yakoob for his critical feedback on the draft. This article has been published as part of BMC Public Health Volume 11 Supplement 3, 2011: Technical inputs, enhancements and applications of the Lives Saved Tool (LiST). The full contents of the supplement are available online at http://www.biomedcentral.com/1471-2458/11?issue=S3.

\section{Authors' contributions}

Professor Zulfiqar A Bhutta developed the parameters for the review and secured support. Dr Aamer Imdad undertook the literature search, data extraction and wrote the manuscript under the supervision of Professor Bhutta.

\section{Competing interests}

We do not have any financial or non-financial competing interests for this review.

Published: 13 April 2011

\section{References}

1. Moynahan EJ: Letter: Acrodermatitis enteropathica: a lethal inherited human zinc-deficiency disorder. Lancet 1974, 2(7877):399-400.

2. Prasad AS: Discovery of human zinc deficiency and studies in an experimental human model. Am J Clin Nutr 1991, 53(2):403-412.

3. Brown KH, Peerson JM, Baker SK, Hess SY: Preventive zinc supplementation among infants, preschoolers, and older prepubertal children. Food Nutr Bull 2009, 30(1 Suppl):S12-40.

4. Brown KH, Peerson JM, Rivera J, Allen LH: Effect of supplemental zinc on the growth and serum zinc concentrations of prepubertal children: a meta-analysis of randomized controlled trials. Am J Clin Nutr 2002, 75(6):1062-1071.

5. Ramakrishnan U, Nguyen P, Martorell R: Effects of micronutrients on growth of children under $5 \mathrm{y}$ of age: meta-analyses of single and multiple nutrient interventions. Am J Clin Nutr 2009, 89(1):191-203.

6. Atkins D, Best D, Briss PA, Eccles M, Falck-Ytter Y, Flottorp S, Guyatt GH, Harbour RT, Haugh MC, Henry D, et al: Grading quality of evidence and strength of recommendations. BMJ 2004, 328(7454):1490. 
7. Walker N, Fischer-Walker C, Bryce J, Bahl R, Cousens S: writing for the CHERG Review Groups on Intervention Effects. Standards for CHERG Reviews of Intervention Effects on Child Survival. IJE 2009.

8. Data - Country Classification. [http://web.worldbank.org/].

9. Hess SY, Brown $\mathrm{KH}$ : Impact of zinc fortification on zinc nutrition. Food Nutr Bull 2009, 30(1 Suppl):S79-107.

10. Walker N, Fischer-Walker C, Bryce J, Bahl R, Cousens S: Standards for CHERG reviews of intervention effects on child survival. Int J Epidemiol 2010, 39(Suppl 1):i21-31.

11. Cohen J: Statistical Power Analysis for the Behavioral Sciences. Hillsdale, NJ: Lawrence Earlbaum Associates; 1988.

12. Hunter JE, Schmidt FL: Methods of meta-analysis: correcting error and bias in research findings. Newbury Park, CA: Sage Publications; 1990.

13. Wolf F: Meta-analysis: quantitative methods for research synthesis. Newbury Park, CA: Sage Publications; 1986.

14. Kordas K, Stoltzfus RJ: New evidence of iron and zinc interplay at the enterocyte and neural tissues. J Nutr 2004, 134(6):1295-1298.

15. Troost FJ, Brummer RJ, Dainty JR, Hoogewerff JA, Bull VJ, Saris WH: Iron supplements inhibit zinc but not copper absorption in vivo in ileostomy subjects. Am J Clin Nutr 2003, 78(5):1018-1023.

16. RevMan: The Cochrane Colloboration. Review Manager (RevMan) 5 for Windows. Oxford England; 2003.

17. Gibson RS, Vanderkooy PD, MacDonald AC, Goldman A, Ryan BA, Berry M: A growth-limiting, mild zinc-deficiency syndrome in some southern Ontario boys with low height percentiles. Am J Clin Nutr 1989, 49(6):1266-1273.

18. Cavan KR, Gibson RS, Grazioso CF, Isalgue AM, Ruz M, Solomons NW: Growth and body composition of periurban Guatemalan children in relation to zinc status: a cross-sectional study. Am J Clin Nutr 1993, 57(3):334-343.

19. Castillo-Duran C, Garcia H, Venegas P, Torrealba I, Panteon E, Concha N, Perez P: Zinc supplementation increases growth velocity of male children and adolescents with short stature. Acta Paediatr 1994, 83(8):833-837.

20. Friis H, Ndhlovu P, Mduluza T, Kaondera K, Sandstrom B, Michaelsen KF, Vennervald BJ, Christensen NO: The impact of zinc supplementation on Schistosoma mansoni reinfection rate and intensities: a randomized, controlled trial among rural Zimbabwean schoolchildren. Eur J Clin Nutr 1997, 51(1):33-37.

21. Sayeg Porto MA, Oliveira HP, Cunha AJ, Miranda G, Guimaraes MM, Oliveira WA, dos Santos DM: Linear growth and zinc supplementation in children with short stature. J Pediatr Endocrinol Metab 2000, 13(8):1121-1128.

22. Udomkesmalee E, Dhanamitta $S$, Sirisinha $S$, Charoenkiatkul $S$, Tuntipopipat S, Banjong O, Rojroongwasinkul N, Kramer TR, Smith JC Jr.: Effect of vitamin A and zinc supplementation on the nutriture of children in Northeast Thailand. Am J Clin Nutr 1992, 56(1):50-57.

23. Walravens PA, Krebs NF, Hambidge KM: Linear growth of low income preschool children receiving a zinc supplement. Am J Clin Nutr 1983, 38(2):195-201.

24. Walravens PA, Hambidge KM, Koepfer DM: Zinc supplementation in infants with a nutritional pattern of failure to thrive: a double-blind, controlled study. Pediatrics 1989, 83(4):532-538.

25. Walravens PA, Chakar A, Mokni R, Denise J, Lemonnier D: Zinc supplements in breastfed infants. Lancet 1992, 340(8821):683-685.

26. Heinig MJ, Brown KH, Lonnerdal B, Dewey KG: Zinc supplementation does not affect growth, morbidity, or motor development of US term breastfed infants at 4-10 mo of age. Am J Clin Nutr 2006, 84(3):594-601.

27. Behrens RH, Tomkins AM, Roy SK: Zinc supplementation during diarrhoea, a fortification against malnutrition? Lancet 1990, 336(8712):442-443.

28. Simmer K, Khanum S, Carlsson L, Thompson RP: Nutritional rehabilitation in Bangladesh-the importance of zinc. Am J Clin Nutr 1988, 47(6):1036-1040.

29. Friel JK, Andrews WL, Matthew JD, Long DR, Cornel AM, Cox M, McKim E, Zerbe GO: Zinc supplementation in very-low-birth-weight infants. J Pediatr Gastroenterol Nutr 1993, 17(1):97-104.

30. Gatheru Z, Kinoti S, Alwar J, Mwita M: Serum zinc levels in children with kwashiorkor aged one to three years at Kenyatta National Hospital and the effect of zinc supplementation during recovery. East Afr Med J 1988, 65(10):670-679.
31. Golden BE, Golden MH: Effect of zinc on lean tissue synthesis during recovery from malnutrition. Eur J Clin Nutr 1992, 46(10):697-706.

32. Khanum S, Alam AN, Anwar I, Akbar Ali M, Mujibur Rahaman M: Effect of zinc supplementation on the dietary intake and weight gain of Bangladeshi children recovering from protein-energy malnutrition. Eur J Clin Nutr 1988, 42(8):709-714.

33. Hong ZY, Zhang YW, Xu JD, Zhou JD, Gao XL, Liu XG, Shi YY: Growth promoting effect of zinc supplementation in infants of high-risk pregnancies. Chin Med J (Engl) 1992, 105(10):844-848.

34. Bates CJ, Evans PH, Dardenne M, Prentice A, Lunn PG, Northrop-Clewes CA, Hoare S, Cole TJ, Horan SJ, Longman SC, et al: A trial of zinc supplementation in young rural Gambian children. Br J Nutr 1993, 69(1):243-255.

35. Dirren H, Barclay D, Ramos JG, Lozano R, Montalvo MM, Davila N, Mora JO: Zinc supplementation and child growth in Ecuador. Adv Exp Med Biol 1994, 352:215-222

36. Castillo-Duran C, Rodriguez A, Venegas G, Alvarez P, Icaza G: Zinc supplementation and growth of infants born small for gestational age. $J$ Pediatr 1995, 127(2):206-211.

37. Ninh NX, Thissen JP, Collette L, Gerard G, Khoi HH, Ketelslegers JM: Zinc supplementation increases growth and circulating insulin-like growth factor I (IGF-I) in growth-retarded Vietnamese children. Am J Clin Nutr 1996, 63(4):514-519.

38. Sempertegui F, Estrella B, Correa E, Aguirre L, Saa B, Torres M, Navarrete F, Alarcon C, Carrion J, Rodriguez, et al: Effects of short-term zinc supplementation on cellular immunity, respiratory symptoms, and growth of malnourished Equadorian children. Eur J Clin Nutr 1996, 50(1):42-46

39. Ruz M, Castillo-Duran C, Lara X, Codoceo J, Rebolledo A, Atalah E: A 14-mo zinc-supplementation trial in apparently healthy Chilean preschool children. Am J Clin Nutr 1997, 66(6):1406-1413.

40. Kikafunda JK, Walker AF, Allan EF, Tumwine JK: Effect of zinc supplementation on growth and body composition of Ugandan preschool children: a randomized, controlled, intervention trial. Am J Clin Nutr 1998, 68(6):1261-1266.

41. Lira Pl, Ashworth A, Morris SS: Effect of zinc supplementation on the morbidity, immune function, and growth of low-birth-weight, full-term infants in northeast Brazil. Am J Clin Nutr 1998, 68(2 Suppl):418S-424S.

42. Meeks Gardner J, Witter MM, Ramdath DD: Zinc supplementation: effects on the growth and morbidity of undernourished Jamaican children. Eur J Clin Nutr 1998, 52(1):34-39.

43. Rivera JA, Ruel MT, Santizo MC, Lonnerdal B, Brown KH: Zinc supplementation improves the growth of stunted rural Guatemalan infants. J Nutr 1998, 128(3):556-562.

44. Smith JC, Makdani D, Hegar A, Rao D, Douglass LW: Vitamin A and zinc supplementation of preschool children. J Am Coll Nutr 1999, 18(3):213-222.

45. Umeta M, West CE, Haidar J, Deurenberg P, Hautvast JG: Zinc supplementation and stunted infants in Ethiopia: a randomised controlled trial. Lancet 2000, 355(9220):2021-2026.

46. Castillo-Duran C, Perales CG, Hertrampf ED, Marin VB, Rivera FA, Icaza G: Effect of zinc supplementation on development and growth of Chilean infants. J Pediatr 2001, 138(2):229-235.

47. Dijkhuizen MA, Wieringa FT, West CE, Martuti S, Muhilal : Effects of iron and zinc supplementation in Indonesian infants on micronutrient status and growth. J Nutr 2001, 131(11):2860-2865.

48. Osendarp SJ, Santosham M, Black RE, Wahed MA, van Raaij JM, Fuchs GJ: Effect of zinc supplementation between 1 and 6 mo of life on growth and morbidity of Bangladeshi infants in urban slums. Am J Clin Nutr 2002, 76(6):1401-1408.

49. Muller O, Garenne M, Reitmaier P, Van Zweeden AB, Kouyate B, Becher H: Effect of zinc supplementation on growth in West African children: a randomized double-blind placebo-controlled trial in rural Burkina Faso. Int J Epidemiol 2003, 32(6):1098-1102.

50. Sur D, Gupta DN, Mondal SK, Ghosh S, Manna B, Rajendran K, Bhattacharya SK: Impact of zinc supplementation on diarrheal morbidity and growth pattern of low birth weight infants in kolkata, India: a randomized, double-blind, placebo-controlled, community-based study. Pediatrics 2003, 112(6 Pt 1):1327-1332.

51. Alarcon K, Kolsteren PW, Prada AM, Chian AM, Velarde RE, Pecho IL, Hoeree TF: Effects of separate delivery of zinc or zinc and vitamin A on 
hemoglobin response, growth, and diarrhea in young Peruvian children receiving iron therapy for anemia. Am J Clin Nutr 2004, 80(5):1276-1282.

52. Black MM, Baqui AH, Zaman K, Ake Persson L, El Arifeen S, Le K, McNary SW, Parveen M, Hamadani JD, Black RE: Iron and zinc supplementation promote motor development and exploratory behavior among Bangladeshi infants. Am J Clin Nutr 2004, 80(4):903-910.

53. Black MM, Sazawal S, Black RE, Khosla S, Kumar J, Menon V: Cognitive and motor development among small-for-gestational-age infants: impact of zinc supplementation, birth weight, and caregiving practices. Pediatrics 2004, 113(5):1297-1305

54. Lind T, Lonnerdal B, Stenlund H, Gamayanti IL, Ismail D, Seswandhana R, Persson LA: A community-based randomized controlled trial of iron and zinc supplementation in Indonesian infants: effects on growth and development. Am J Clin Nutr 2004, 80(3):729-736.

55. Penny ME, Marin RM, Duran A, Peerson JM, Lanata CF, Lonnerdal B, Black RE, Brown KH: Randomized controlled trial of the effect of daily supplementation with zinc or multiple micronutrients on the morbidity, growth, and micronutrient status of young Peruvian children. Am J Clin Nutr 2004, 79(3):457-465.

56. Brooks WA, Santosham M, Naheed A, Goswami D, Wahed MA, DienerWest M, Faruque AS, Black RE: Effect of weekly zinc supplements on incidence of pneumonia and diarrhoea in children younger than 2 years in an urban, low-income population in Bangladesh: randomised controlled trial. Lancet 2005, 366(9490):999-1004.

57. Gardner JM, Powell CA, Baker-Henningham H, Walker SP, Cole TJ, Grantham-McGregor SM: Zinc supplementation and psychosocial stimulation: effects on the development of undernourished Jamaican children. Am J Clin Nutr 2005, 82(2):399-405.

58. Berger J, Ninh NX, Khan NC, Nhien NV, Lien DK, Trung NQ, Khoi HH: Efficacy of combined iron and zinc supplementation on micronutrient status and growth in Vietnamese infants. Eur J Clin Nutr 2006, 60(4):443-454.

59. Olney DK, Pollitt E, Kariger PK, Khalfan SS, Ali NS, Tielsch JM, Sazawal S, Black R, Allen LH, Stoltzfus RJ: Combined iron and folic acid supplementation with or without zinc reduces time to walking unassisted among Zanzibari infants 5- to 11 -mo old. J Nutr 2006, 136(9):2427-2434.

60. Silva AP, Vitolo MR, Zara LF, Castro CF: Effects of zinc supplementation on 1- to 5-year old children. J Pediatr (Rio J) 2006, 82(3):227-231.

61. Wasantwisut $E$, Winichagoon $P$, Chitchumroonchokchai $C$, Yamborisut $U$, Boonpraderm A, Pongcharoen T, Sranacharoenpong K, Russameesopaphorn W: Iron and zinc supplementation improved iron and zinc status, but not physical growth, of apparently healthy, breastfed infants in rural communities of northeast Thailand. J Nutr 2006, 136(9):2405-2411.

62. Fahmida U, Rumawas JS, Utomo B, Patmonodewo S, Schultink W: Zinc-iron, but not zinc-alone supplementation, increased linear growth of stunted infants with low haemoglobin. Asia Pac J Clin Nutr 2007, 16(2):301-309.

63. Dijkhuizen MA, Winichagoon P, Wieringa FT, Wasantwisut E, Utomo B, Ninh NX, Hidayat A, Berger J: Zinc supplementation improved length growth only in anemic infants in a multi-country trial of iron and zinc supplementation in South-East Asia. J Nutr 2008, 138(10):1969-1975.

64. Wuehler SE, Sempertegui F, Brown KH: Dose-response trial of prophylactic zinc supplements, with or without copper, in young Ecuadorian children at risk of zinc deficiency. Am J Clin Nutr 2008, 87(3):723-733.

65. Fischer Walker $\mathrm{CL}$, Baqui AH, Ahmed S, Zaman K, El Arifeen S, Begum N, Yunus M, Black RE, Caulfield LE: Low-dose weekly supplementation of iron and/or zinc does not affect growth among Bangladeshi infants. Eur I Clin Nutr 2009, 63(1):87-92

66. Mozaffari-Khosravi H, Shakiba M, Eftekhari MH, Fatehi F: Effects of zinc supplementation on physical growth in 2-5-year-old children. Biol Trace Elem Res 2009, 128(2):118-127.

67. Brown KH, Lopez de Romana D, Arsenault JE, Peerson JM, Penny ME: Comparison of the effects of zinc delivered in a fortified food or a liquid supplement on the growth, morbidity, and plasma zinc concentrations of young Peruvian children. Am J Clin Nutr 2007, 85(2):538-547.

68. Rosado JL, Lopez P, Munoz E, Martinez H, Allen LH: Zinc supplementation reduced morbidity, but neither zinc nor iron supplementation affected growth or body composition of Mexican preschoolers. Am J Clin Nutr 1997, 65(1):13-19.
69. Cochrane Handbook for Systematic Reviews of Interventions. Higgins JPT, Green S 2008 [http://www.cochrane-handbook.org], Version 5.0.2 [updated September 2009].

70. Bhutta ZA, Ahmed T, Black RE, Cousens S, Dewey K, Giugliani E, Haider BA Kirkwood B, Morris SS, Sachdev HP, et al: What works? Interventions for maternal and child undernutrition and survival. Lancet 2008, 371(9610):417-440

71. Imdad A, Yakoob MY, Bhutta ZA: Impact of maternal education about complementary feeding and provision of complementary foods on child growth in developing countries. BMC Public Health 2011, 11(Suppl 3):S25.

72. Garrick MD, Dolan KG, Horbinski C, Ghio AJ, Higgins D, Porubcin M, Moore EG, Hainsworth LN, Umbreit JN, Conrad ME, et al: DMT1: a mammalian transporter for multiple metals. Biometals 2003, 16(1):41-54.

73. Arredondo M, Martinez R, Nunez MT, Ruz M, Olivares M: Inhibition of iron and copper uptake by iron, copper and zinc. Biol Res 2006, 39(1):95-102.

74. Doherty CP, Sarkar MA, Shakur MS, Ling SC, Elton RA, Cutting WA: Zinc and rehabilitation from severe protein-energy malnutrition: higher-dose regimens are associated with increased mortality. Am J Clin Nutr 1998, 68(3):742-748.

75. Higashi A, Ikeda T, Iribe $K$, Matsuda I: Zinc balance in premature infants given the minimal dietary zinc requirement. J Pediatr 1988, 112(2):262-266.

76. Hansen M, Samman S, Madsen LT, Jensen M, Sorensen SS, Sandstrom B: Folic acid enrichment of bread does not appear to affect zinc absorption in young women. Am J Clin Nutr 2001, 74:125-129.

77. López de Romaña D, Salazar M, Hambidge KM, Penny ME, Peerson JM, Krebs NF, Brown KH: Longitudinal measurements of zinc absorption in Peruvian children consuming wheat products fortified with iron only or iron and 1 of 2 amounts of zinc. Am J Clin Nutr 2005, 81:637-647.

78. Sandström B, Arvidsson B, Cederblad A, Bjorn-Rasmussen E: Zinc absorption from composite meals.I.The significance of wheat extraction rate, zinc, calcium, and protein content in meals based on bread. Am $J$ Clin Nutr 1980, 739-745.

79. Kupka R, Fawzi W: Zinc nutrition and HIV infection. Nutr Rev 2002, 60(3):69-79.

80. Webb P, Nishida C, Darnton-Hill I: Age and gender as factors in the distribution of global micronutrient deficiencies. Nutr Rev 2007, 65:233-245.

81. Bobat R, Coovadia H, Stephen C, Naidoo KL, McKerrow N, Black RE, Moss WJ: Safety and efficacy of zinc supplementation for children with HIV-1 infection in South Africa: a randomised double-blind placebocontrolled trial. Lancet 2005, 366(9500):1862-1867.

doi:10.1186/1471-2458-11-S3-S22

Cite this article as: Imdad and Bhutta: Effect of preventive zinc supplementation on linear growth in children under 5 years of age in developing countries: a meta-analysis of studies for input to the lives saved tool. BMC Public Health 2011 11(Suppl 3):S22.

\section{Submit your next manuscript to BioMed Central and take full advantage of:}

- Convenient online submission

- Thorough peer review

- No space constraints or color figure charges

- Immediate publication on acceptance

- Inclusion in PubMed, CAS, Scopus and Google Scholar

- Research which is freely available for redistribution

Submit your manuscript at www.biomedcentral.com/submit
C Biomed Central 